\title{
Pengaturan Perlindungan Hukum Terhadap Pengguna Jasa Transportasi di Darat atas Kehilangan dan Kerusakan Barang Kiriman
}

\author{
Fatahillah $^{1}$ \\ Dosen Fakultas Hukum Universitas Malikussaleh \\ fatahillahsh@yahoo.co.id
}

\begin{abstract}
Under the provisions of law number 22 of 2009 on traffic and road transport in article 193 states the responsibility of transport companies losses. Article 193 mentions the liability rules on compensation of corporate transportation. In the implementation of the transport was not immune from problems, such as broken, lost and late to the purpose it is due to the negligence of the transport or due to circumstances unforeseen for goods shipped to the detriment of the shipper, or may be carrying less attention to security and safety in the transport goods. In the case of dispute resolution to be taken as a result of damage and loss of goods to get right back to efforts to produce a consensus agreement between the parties. The completion of the deliberation will usually produce an agreement with the results of each of the parties mutually beneficial in order to maintain the good name of company transport services and service users are not unduly disadvantaged.
\end{abstract}

Keywords:

Legal Protection, User Transportation Services, Loss and Damage Goods

\begin{abstract}
Abstrak
Berdasarkan ketentuan undang-undang Nomor 22 Tahun 2009 Tentang Rambu-Rambu Lalu Lintas dan Angkutan Darat, Pasal 193 menyebutkan tentang aturan pertanggungjawaban tentang ganti rugi dari perusahan transportasi. Dalam pelaksanaan pengangkutan juga tidak luput dari berbagai persoalan, misalnya rusak, hilang dan terlambat sampai tujuan hal ini disebabkan karena kelalaian pengangkutan maupun akibat terjadinya keadaan tidak terduga terhadap barang yang dikirim sehingga merugikan pihak pengirim, atau bisa saja pengangkut kurang memperhatikan keamanan dan keselamatan dalam pengangkutan barang tersebut. Dalam hal penyelesaian sengketa yang ditempuh akibat kerusakan dan kehilangan barang untuk mendapat haknya kembali bisa dilakukan upaya musyawarah sehingga menghasilkan kesepakatan antara para pihak. Penyelesaian dengan cara musyawarah biasanya akan menghasilkan kesepakatan dengan hasil masing-masing pihak saling menguntungkan demi menjaga nama baik dari perusahaan jasa angkutan dan pengguna jasa tidak terlalu dirugikan.
\end{abstract}

Kata Kunci:

Perlindungan Hukum, Pengguna Jasa Transportasi, Kehilangan dan Kerusakan Barang 


\section{A. PENDAHULUAN}

Hukum adalah himpunan petunjuk hidup-perintah dan larangan yang mengatur tata tertib dalam suatu masyarakat, dan seharusnya ditaati oleh seluruh anggota masyarakat yang bersangkutan, oleh karena itu pelanggaran petunjuk hidup tersebut dapat menimbulkan tindakan oleh pemerintah atau penguasa itu 1 . Hukum yang meliputi: (1) hukum dalam arti ketentuan penguasa undang-undang, keputusan hakim dan sebagainya), (2) hukum dalam arti petugas-petugas-nya (penegak hukum), (3) hukum dalam arti sikap tindak, (4) hukum dalam arti sistem kaidah, (5) hukum dalam arti jalinan nilai (tujuan hukum), (6) hukum dalam arti tata hukum, (7) hukum dalam arti ilmu hukum, (8) hukum dalam arti disiplin hukum. ${ }^{2}$ Salah satu contohnya adalah adanya hukum pengangkutan yang berfungsi untuk mengatur lalu lintas barang baik dalam negeri ataupun luar negeri.

1 E. Utrecht, Moh. Saleh Djindang, Pengantar Dalam Hukum Indonesia, Cetakan. Kesebelas, Penerbit PT. Ichtiar Baru, Jakarta, 1983. hlm. 10

2 Soedjono Dirjosisworo, Pengantar Ilmu Hukum, edisi I cetakan 14, Rajawali Pers, Jakarta, 2010, hlm. 10
Hukum pengangkutan merupakan bagian dari hukum dagang (perusahaan) dan hukum dagang (perusahaan) termasuk dalam bidang hukum keperdataan. Dilihat dari segi susunan hukum normatif, bidang hukum keperdataan adalah sub-sistem tata hukum nasional. Jadi, hukum dagang (perusahaan) termasuk dalam sus-sistem tata hukum nasional. Asasasas tata hukum nasional adalah juga asas-asas hukum pengangkutan. ${ }^{3}$

Adanya hukum pengangkutan sangat diperlukan untuk mengatur dan melindungi pengguna jasa. Jasa pengangkutan di Indonesia mengalami berbagai kemajuan dengan adanya perusahaanperusahaan jasa pengangkutan sehingga dapat memperlancar arus barang dari daerah produksi ke konsumen sehingga perdagangan barang baik dalam negeri dan luar negeri menjadi lancar pula.

\section{Pengangkutan, ${ }^{4}$ diadakannya untuk memindahkan barang dari}

3 Abdul Kadir Muhammad, Hukum Pengangkutan Darat, Laut, dan Udara, Penerbit PT. Citra Aditya Bakti, Bandung, 1991, hlm. 10

4 Pengangkutan adalah perjanjian timbal balik antara pengangkut dengan pengirim, dimana pengangkut mengikatkan diri untuk menyelenggarakan pengangkutan barang 
tempat asal ke tempat tujuan untuk mencapai dan meninggikan manfaat serta efisiensi. Pengangkutan terjadi karena adanya suatu perjanjian ${ }^{5}$ antara kedua pihak, yaitu pihak pemberi jasa pengangkutan dengan pemakai jasa. Pihak dalam perjanjian pengangkut adalah dan pengirim. Sifat dari perjanjian pengangkutan adalah perjanjian timbal balik, artinya masing-masing pihak mempunyai kewajiban-kewajiban sendiri-sendiri. Pihak pengangkut berkewajiban untuk menyelenggarakan pengangkutan barang atau orang dari suatu tempat ketempat tujuan tertentu dengan selamat, sedangkan pengirim berkewajiban untuk membayar uang angkutan. Dengan adanya perjanjian tersebut menyebabkan suatu tanggung jawab bagi pengangkut yang terletak pada keamanan dan

dan/atau orang dari suatu tempat ke tempat tujuan tertentu dengan selamat, sedangkan pengirim mengikatkan diri untuk membayar uang angkutan. Purwosutjipto, Pengertian pokok Hukum Dagang Indonesia 3, HukumPengangkutan, Djambatan, Jakarta, 1991, hlm. 2. Sedangkan Menurut Abdul Kadir Muhammad, pengangkutan artinya pengangkatan dan pembawaan barang atau orang, pemuatan dan pengiriman barang atau orang, barang atau orang yang diangkut. Jadi, dalam pengertian pengangkutan itu tersimpul suatu proses kegiatan atau gerakan dari satu tempat ke tempat lain. Abdul Kadir Muhammad, Hukum Pengangkutan Darat, Laut, dan keselamatan serta muatannya terutama pada saat pelayaran atau selama dalam pengangkutan.

Pengangkutan merupakan kegiatan transportasi dalam memindahkan barang dan penumpang dari satu tempat ke tempat lain atau dapat dikatakan sebagai kegiatan ekspedisi. Purwosutjipto berpendapat bahwa: 6

"Pengangkutan adalah perjanjian timbal-balik antara pengangkut dengan pengirim, dimana pengangkut mengikatkan diri untuk menyelenggarakan pengangkutan barang dan/atau orang dari suatu tempat ke tempat tujuan tertentu dengan selamat, sedangkan pengirim mengikatkan diri untuk membayar uang angkutan".

Sebagai suatu kegiatan jasa dalam memindahkan barang atau pun penumpang dari suatu tempat ke tempat lain, pengangkutan berperan

Udara, Penerbit PT. Citra Aditya Bakti, Bandung, 1991, hlm 19.

5 Ibid. hlm. 20-21. Perjanjian pengangkutan adalah persetujuan dengan mana pengangkut mengikatkan diri untuk menyelenggarakan pengangkutan barang dan atau penumpang dari suatu tempat ke tempat tujuan tertentu dengan selamat, dan pengirim atau penumpang mengikatkan diri untuk membayar biaya pengangkutan.

6 H.M.N. Purwosutjipto, Pengertian Pokok Hukum Dagang, Jilid I, Djambatan, Jakarta, 1999. 
sekali dalam mewujudkan terciptanya pola distribusi nasional yang dinamis.

Praktik penyelenggaraan suatu pengangkutan harus dapat memberikan nilai guna yang sebesarbesarnya dalam dunia perdagangan. Serta dalam pelaksanaannya harus dilakukan secara adil dan merata kepada segenap lapisan masyarakat dan lebih mengutamakan kepentingan pelayanan umum bagi masyarakat.

\section{Fungsi Pengangkutan}

Pengangkutan berfungsi untuk memindahkan barang atau orang dari suatu tempat ke tempat yang lain dengan maksud untuk meningkatkan daya guna dan nilai. Proses pemindahan barang tersebut dilakukan melalui darat, laut, udara dan perairan darat atau sungai dengan menggunakan berbagai jenis alat transportasi sesuai dengan kebutuhannya.

Untuk menjamin kepastian dan ketertiban hukum, setiap pelaksanaan pengangkutan melalui khususnya dalam hal pengangkutan barang haruslah sesuai dengan peraturan perundang-undangan yang berlaku. Hal tersebut harus ditangani

7 Black, Henry Campbell, Black's Law Dictionary, USA: West Publishing, 1968. secara nasional agar terwujudnya suatu sistem pola distribusi nasional yang dinamis sehingga dapat meningkatkan daya guna dan nilai.

Pelaksanaan di sektor pengangkutan antara lain diarahkan untuk meningkatkan kegiatan perdagangan antar wilayah pulau (inter insuler) serta perdagangan antar negara (import-export). Adanya arus perpindahan barang dan jasa melalui kegiatan perdagangan tersebut, maka keberadaan perusahaan jasa pengangkutan, perusahaan jasa pengangkutan darat dan serta perusahaan jasa yang memiliki keterkaitan dengan kegiatan pengangkutan melalui darat seperti ekspeditur atau memiliki peranan yang sangat besar.

Ekspeditur menurut Pasal 86 KUHD adalah Orang, yang pekerjaannya menyuruh orang lain untuk menyelenggarakan pengangkutan barang-barang dagangan dan barang-barang lainnya melalui daratan atau perairan. Selain itu definisi mengenai ekspeditur atau dalam Black's Law. ${ }^{7}$ adalah: 
"A person or company whose bussiness is to receive and ship goods for others. A freight forwarder may be an agent of the cargo's owner or of the carrier, or may be an independent contractor acting as a principal and assuming the carrier's responsibility for delivering the cargo.- Also termed third-party logistical service provider, forwarding agent."

Ekspeditur tidak menyelenggarakan pengangkutan terhadap barang muatan tersebut, yang bertugas untuk menyelenggarakan pengangkutan barang muatan tersebut adalah pengangkut. Ekspeditur merupakan subjek hukum pengangkutan karena mempunyai hubungan yang sangat erat dengan pengirim, pengangkut serta penerima barang. Hal itu didasari dengan adanya suatu perjanjian pengangkutan yang dibuat antara ekspeditur dengan pengangkut. Sehingga mengakibatkan ekspeditur berfungsi sebagai perantara yang mewakili pengirim terhadap pihak pengangkut. Untuk itu ekspeditur dapat bertindak atas nama pengirim. Sebagai wakil pengirim dan dapat pula sebagai penerima, ekspeditur mengurus berbagai macam dokumen dan formalitas yang berlaku guna memasukkan dan mengeluarkan barang dari alat angkut atau gudang stasiun, pelabuhan dan maupun bandara.

Prinsip tanggung jawab ekspeditur dapat ditemukan di dalam Pasal 87 KUHD: "Ia harus menanggung, bahwa pengiriman barang-barang dagangan dan lainnya yang untuk itu diterimanya, akan mendapatkan penyelenggaraannya dengan rapi dan dengan selekaslekasnya, pula dengan mengindahkan segala upaya, yang sanggup menjamin keselamatan barang-barang yang diangkutnya."

Pasal 87 KUHD tersebut menetapkan tanggung jawab ekspeditur terhadap barang-barang yang telah diserahkan pengirim kepadanya untuk:

1. Menyelenggarakan pengiriman secepatnya dengan rapi pada barang yang telah diterimanya dari pengirim;

2. Mengindahkan segala upaya untuk menjamin keselamatan barangbarang tersebut;

3. Pengambilan barang-barang dari gudang pengirim;

4. Melakukan penyimpanan di gudang miliknya;

5. Pengambilan barang muatan dari pelabuhan tujuan untuk 
diserahkan kepada penerima yang berhak atau kepada pengangkut selanjutnya.

Efektifitas aturan hukum sangat penting dalam kaitannya dengan bekerjanya aturan hukum tersebut dalam praktek pengangkutan. Clarence J. Dias ${ }^{8}$ menyatakan bahwa efektifitas suatu sistem hukum ditentukan oleh lima syarat sebagai berikut:

1. Mudah tidaknya makna atau isi aturan-aturan hukum itu ditangkap dan dipahami.

2. Luas tidaknya kalangan di dalam masyarakat yang mengetahui isi aturan-aturan hukum itu.

3. Efesien dan efektif tidaknya mobilisasi aturan-aturan hukum yang dicapai dengan bantuan

4. Aparat administrasi yang menyadari kewajibannya untuk melibatkan diri ke dalam usaha mobilisasi yang demikian itu;

\section{Peran Serta Masyarakat/ Mekanisme Penyelesaian Masalah}

Para warga masyarakat yang merasa harus berpartisipasi di dalam proses mobilisasi hukum. Adanya mekanisme penyelesaian sengketa yang tidak hanya mudah dihubungi dan dimasuki oleh setiap warga masyarakat akan tetapi juga harus cukup efektif menyelesaikan sengketasengketa itu. Adanya anggapan dan pengakuan yang merata di kalangan masyarakat bahwa aturan-aturan dan pranata-pranata hukum itu memang sesungguhnyalah berdaya kemampuan efektif.

Clarence J. Dias, berpendapat diharapkan suatu perundangundangan yang telah dibentuk dengan baik menurut asas-asas hukum, pada hakikatnya akan memudahkan penerapan perundang-undangan tersebut di lapangan dan akan memberikan kepastian hukum yang bersandar pada nilai-nilai keadilan bagi masyarakat.

Aturan-aturan tersebut diharapkan mampu melindungi hak dan kewajiban para pihak yang terlibat dalam bidang pengangkutan, terutama dalam hal tanggung jawab atas kerusakan barang yang diangkut. Dalam hal ini pihak pengangkut dan ekspeditur wajib berdasarkan aturan perundang-undangan yang berlaku menjaga barang yang dikirimnya atau

8 Black, Henry Campbell, Black's Law Dictionary, USA: West Publishing, 1968. 
diangkutnya agar tidak rusak atau pun tidak menimbulkan kerugian bagi si pemilik barang.

Hukum pengangkutan apabila dikaitkan dengan konsepsi "The Economic Theory of Regulation" yang dikemukakan oleh Richard A. Posner, maka hukum pengangkutan merupakan sarana keteraturan atau ketertiban yang dibutuhkan dalam menyalurkan kegiatan perdagangan antar pulau ke arah yang dikehendaki oleh suatu pembangunan. Sehingga hal tersebut telah sesuai dengan fungsi dasar hukum yakni menjamin adanya kepastian dan ketertiban serta memberikan manfaat bagi perkembangan industri pengangkutan tersebut.

Indonesia sebagai negara yang berkembang dan sedang membangun memerlukan peran dan fungsi hukum sebagai sarana menjamin kepastian dan ketertiban serta memberikan perlindungan bagi setiap warga negara Indonesia. Peran dan fungsi hukum di negara berkembang tidaklah lebih mudah daripada di negara maju, karena terdapatnya berbagai keterbatasan yang bukan saja mengurangi kelancaran lajunya proses hukum secara tertib dan pasti tetapi juga memerlukan pendekatan dan pemikiran-pemikiran yang menuju kepada suatu konstruksi hukum yang adaptif yang dapat menyeimbangkan berbagai kepentingan yang ada secara mantap dan responsif.

Hukum berfungsi sebagai perlindungan kepentingan manusia. Agar kepentingan manusia terlindungi, hukum harus dilaksanakan. Pelaksanaan hukum dapat berlangsung secara normal, damai, tetapi dapat terjadi juga karena pelanggaran hukum. Dalam hal ini hukum yang telah dilanggar itu harus ditegakan. Melalui penegakan hukum inilah hukum itu menjadi kenyataan. "Dalam menegakan hukum ada tiga unsur yang selalu harus diperhatikan, yaitu kepastian hukum (Rechtssicherheit), kemanfaatan (Zweckmassigkeit) dan keadilan (Gerechtigkeit)."

Menurut Sudikno Mertokusumo, masyarakat mengharapkan manfaat dalam pelaksanaan atau penegakan hukum dalam hal terjadi peristiwa yang konkrit, Bagaimana hukumnya itulah yang harus berlaku. Masyarakat mengharapkan adanya kepastian hukum, karena dengan adanya kepastian hukum masyarakat akan lebih tertib. Hukum bertugas 
menciptakan kepastian hukum karena bertujuan ketertiban masyarakat.

Di samping terciptanya kepastian, ketertiban dan perlindungan hukum negara juga mempunyai kewajiban untuk mengusahakan kesejahteraan bagi segenap warga negaranya. Menyelenggarakan kesejahteraan umum merupakan konsekuensi logis dan diterimanya konsep Negara kesejahteraan) (welfare state) atau konsep tentang negara hukum yang dinamis sejak awal abad XX (dua puluh).

Dalam Kitab Undang-Undang Hukum Dagang (KUHD) mengenai tanggung jawab pengangkut diatur dalam Pasal 91 yaitu " Pengangkutan dan juragan perahu harus menanggung segala kerusakan yang terjadi pada barang-barang dagangan dan lainnya setelah barang itu mereka terima untuk diangkut, kecuali kerusakan yang diakibatkan karena sesuatu cacat pada barang itu sendiri karena keadaan yang memaksa, atau karena kesalahan atau kealpaan sipengirim"

$$
\text { Yang mengatur tentang }
$$
tanggung jawab pengangkut terhadap keselamatan barang yang diangkut diautr dalam pasal 468 yaitu:

a) Persetujuan pengangkutan mewajibkan sipengankut untuk menjaga akan keselamatan barang yang harus diangkutnya, mulai saat diterimanya hingga saat diserahkan barang tersebut.

b) $\mathrm{Si}$ Pengangkut diwajibkan mengganti segala kerugian, yang disebabkan karena barang tersebut seluruhnya atau sebagian tidak dapat diserahkannya, atau karena terjadi kerusakan pada barang itu, kecuali apabila dibuktikannya bahwa tidak diserahkannya barang atau kerusakan tadi, disebabkan oleh suatu malapetaka yang selayaknya tidak dapat dicegah naupun dihindarkannya atau cacat dari pada barang tersebut, atau oleh kesalahan dari si yang mengirimkannya.

c) Ia bertanggung jawab untuk perbuatan dari segala mereka, yang dipekerjakannya dan untuk segala benda yang dipakainnya dalam menyelenggarakan pengangkutan tersebut.

Isi dari kedua pasal tersebut diatas tampak bahwa pengangkut bertanggung jawab terhadap 
keselamatan barang yang diangkutnya sejak saat ia menerimanya dari pengirim hingga ia menyerahkan pada penerima barang, pengangkut wajib mengganti kerugian yang ditimbulkan kepada pihak yang dirugikan, apabila kerugian tersebut disebabkan kelalaian atau kesalahan dari pihak pengangkut.

\section{B. RUMUSAN MASALAH}

Berdasarkan latar belakang
permasalahan yang telah
dikemukakan di atas, maka dapat
dirumuskan beberapa masalah,antara
lain faktor apa yang menyebabkan
rusaknya barang serta bagaimana
penyelesaian apabila terjadi kerugian
yang dialami oleh konsumen pengguna
jasa angkutan.

\section{METODE PENELITIAN}

Penelitian ini menggunakan metode penelitan Yuridis Normatif. Penggunaan pendekatan Yuridis sosiolgis. ${ }^{9} \quad$ Ditujukan terhadap sistematika dan konsistensi kaedah (norma-norma) hukum mulai dari Undang-Undang Dasar 1945, UndangUndang, Peraturan Pemerintah, dan Peraturan petunjuk pelaksana lainnya, selain itu juga asas-asas dan proses terbentuknya kaedah norma tersebut , data sekunder dikumpulkan melalui studi dokumen, bahan kepustakaan dan dokumen-dokumen hasil putusan yang merupakan yurisprudensi.

\section{PEMBAHASAN}

Berdasarkan hasil penelitian bahwa di dalam perjanjian pengangkutan barang melalui perusahaan angkutan khususnya di darat, sebagaimana di dalam perjanjian pada umumnya para pihak mempunyai hak dan kewajiban. Perusahaan pengangkutan yang bertindak sebagai pengangkut harus melakukan kewajiban dengan apa yang diperjanjikan, dalam melaksanakan kewajiban harus diiringi dengan tanggung jawab, dan tanpa tanggung jawab prestasi tidak akan terjadi.

Para pengguna jasa angkutan dalam hal ini pengirim barang juga harus memenuhi syarat yang ditentukan mengenai misalnya biaya. Atau tarif angkutan barang dapat dilihat dari tarif yang ditetapkan oleh perusahaan angkutan pada

9 Roni Hanitijo Soemitro, Metode Penelitian Hukum dan Jurimetri . Ghalia Indonesia, Jakarta. 1988, hal.11 
perusahaan jasa pengangkutan tersebut.

Kemudian realisasi atau pemenuhan prestasi apa yang diperjanjikan maka apa yang telah disepakati maka harus dilaksanakan atau dipenuhi oleh para pihak. Dalam pelaksanaan pengangkutan juga tidak luput dari berbagai persoalan, misalnya rusak, hilang dan terlambat sampai tujuan hal ini disebabkna bisa karna kelalaian pengangkutan maupun akibat terjadinya keadaan tidak terduga terhadap barang yang dikirim sehingga merugikan pihak pengirim, bisa saja pengangkut kurang memperhatikan keamanan dan keselamata dalam pengangkutan barang tersebut.

Berdasarkan hasil evaluasi terhadap sebuah perusahaan jasa angkutan Barang CV Berdikari trayek dari Medan ke Aceh dari Tahun 2009 sampai tahun 2013 terjadi , 7.866 kali pengiriman telah terjadi kehilangan 6 kasus, Kerusakan barang 15 kasus, keterlambatan 24 kasus. Kemudian Perusahaan Jasa Pengangkutan CV Jasa Ekspres Trayek dari Medan ke Banda Aceh sejak tahun 2009 sampai tahun 2011 terjadi 19 kasus kerusakan baranag kiriman serta 3 kasus kehilangan barang kiriman.

Berdasarkan hasil penelitian adanya pengirim meminta ganti rugi pada perusahaan angkutan tersebut karena rusaknya barang serta kehilangan barang adapun jenis barang antara lain, Barang elektronik, barang pecah belah, serta spare part kenderaan, kondisi ini mengakibatkan kerugian bagi pemilik barang yang telah membayar ongkos serta barang tidak sampai di tempat. Berdasarkan ketentuan Pasal 191 ayat (1) UULLAJ, bahwa perusahaan angkutan umum bertanggung jawab atas kerugian yang diakibatkan oleh segala perbuatan orang yang dipekerjakan dalam kegiatan penyelenggara angkutan.

Di dalam Pasal 193 ayat (1) UULLAJ, juga menentukan bahwa perusahaan angkutan umum bertanggung jawab atas kerugian yang diderita oleh pengirim barang karena barang musnah, hilang atau rusaknya barang disebabkan oleh suatu kejadian yang tidak dapat dicegah atau dihindari atau kesalahan pengiriman. Akan tetapi dalam prakteknya diketahui bahwa pihak perusahaan pengangkutan guna melepaskan diri dari tanggung jawab atau ketentuan 
dari perusahaan yang mengulurngulur waktu serta dengan berbagai alasan untuk menghindari dari tanggung jawab. Dalam hal ini menunjukkan pengirim berada dalam posisi lemah, karena seharusnya mendapat pelayanan yang baik akan tetapi karena dalam praktek perjanjian pengiriman barang kurang memahami isi perjanjian yang tertulis karna isi perjanjian bersifat baku.

$$
\begin{aligned}
& \text { Berdasarkan hasil penelitian } \\
& \text { ada beberapa faktor yang } \\
& \text { menyebabkan } \\
& \text { pengangkutan tidak berjalan dengan } \\
& \text { baik yaitu: }
\end{aligned}
$$

\section{Kesalahan dan kelalaian pengangkut}

Faktor rusaknya barang kiriman bisa karena pengepakan barang yang kurang bagus, walaupun barang tersebut sampai ketempat tujuan namun kondisinya rusak atau tidak sempurna.10 Dalam hal ini pengankut bertanggung jawab untuk membayar ganti rugi atas kerusakan barang kiriman karena kelalaian pengangkut yang menyebabkan kerugian pihak pengirim. Perusahaan pengangkut bertanggung jawab atas

10 Andi dan Usman Karyawan CV Berdikari Cabang Banda Aceh Wawancara Tanggal 23 Maret 2012. kerusakan ataupun hilang yang mengakibatkan sebagian atau seluruh seluruh isi barang tersebut rusak, ini karena pihak pengangkut tidak berhati hati dalam pengaturan barang dan penurunan barang atau pembongkaran barang di tempat tujuan yang mengakibakan rusaknya barang tersebut.

\section{Tanggung Jawab Perusahaan Pengangkut Terhadap kerugian Yang di Derita Pengirim}

Tanggung jawab dapat diketahui dari kewajiban yang telah ditetapkan dalam perjanjian atau Undang-Undang Kewajiban Pengangkutan adalah menyelenggarakan pengangkutan, kewajiban ini mengikat sejak pengirim mulai melunasi biaya angkutan.11 Perjanjian telah mem,enuhi syarat sebagaimana diatur dalam Pasal 1320 KUH Perdata, yang mana isi perjanjian tidak boleh bertentanga dengan Undang-Undang, ketertiban umum, serta disetujui para pihak, sebenarnya pengangkutan berkewajiban untuk menganti segala kerugian yang diderita oleh pengirirm sebagai akibat kesalahan pengangkutan maka ia bertanggung jawab,

11 Komar Kanta, Tanggung Jawab Profesional, Ghalia Indonesia, Jakarta, 1994. hlm. 3 
tetapi kalau kesalahan dari pengirim maka pengangkutan tidak bertanggung jawa. Tanggung jawa Perusahaan pengangkutan seperti isi Pasal 193 (1) UULLAJ adalah perusahaan angkutan umum bertanggung jawab atas kerugian yang diderita oleh pengirim barang karena barang musnah, hilang, atau rusaknya barang disebabkan oleh suatu kejadian yang tidak dapat dicegah atau dihindari atau kesalahan pengirim.

\section{Penyelesaian Ganti Rugi Dalam Pengiriman Barang}

Bersarkan pada pasal 193

UULAJ dan perjanjian sebelumnya yang telah disepakati, pihak pengangkut terikat dengan tanggung jawab untuk menganti segala kerugian yang timbul didalam pelaksanaan pengangkutan, apabila kerugian tersebut timbul karena kesalahan atau kelalaian pihak pengangkut. Dalam perjajian para pihak selalu menutut prestasi sesuai dengan perjanjian yang disepakati bersama, akan tetapi tidak semua dan selamanya perjanjian berjalam sebagaimana apa yang btelah disepakati, sehingga timbulnya peselisihan yang berujung timbul sengketa. Penyelesaian secara musyawarah sudah sering terjadi di dunia pengangkutan apabila ada tuntutan ganti rugi dari pihak pengirim akibat tidak utuh atau rusaknya barang yang di angkut. Dalam prakteknya biasanya Pihak angkutan membayar sebesar 10 kali ongkos kirim karena pihak perusahaan menilai barang berdasarkan prosentase ongkos kirim, dalam hal ini pihak pengirim selalu mengalami kerugian.

Berdasarkan hasil penelitian penyelesaian sengketa perjanjian pengangkutan yang menyebabkan kerugian diderita pengirimyang dilakukan pengangkut kebiasaan diselesaikan melalui musyawarah, pembayaran ganti rugi secara tunai biasanya dilakukan kesepakatan mengenai jenis atau bentuk ganti rugi oleh perusahaan setelah adanya kesepakatan pada waktu pembayaran ganti rugi. Sedangkan pembayaran ganti rugi secara cicilan akan dibayar oleh pihak perusahaan secara bertahap pengirim sesuai dengan kesepakatan. Dengan demikian jelaslah bahwa didalam pelaksanaan perjanjian kenyataanya sering menyebabkan salah stu pihak menderita kerugian, meskipun hal ini tidak dikehendaki oleh para pihak yang terikat perjanjian tersebut. 


\section{E. KESIMPULAN}

Adapun faktor yang menyebabkan sering terjadinya kerusakan dan kehilangan barang sering disebabkan oleh kelalaian dari pihak pengangkut dalam penempatan dan pengepakan barang dalam hal kehilangan, kerusakan barang pihak pengguna jasa dapat melakukan upaya ganti rugidari perusahaan angkutan sesuai apa yang tertera dalam Pasal 193 UULLAJ. Dalam hal penyelesaian sengketa yang ditempuh akibat kerusakan dan kehilangan barang untuk mendapat haknya kembali bisa dilakukan upaya musyawarah sehingga menghasilkan kesepakatan antara para pihak. Penyelesaian dengan cara musyawarah biasanya akan menghasilkan kesepakatan dengan hasil masing-masing pihak saling menguntungkan demi menjaga nama baik dari perusahaan jasa angkutan dan pengguna jasa tidak terlalu dirugikan.

\section{DAFTAR PUSTAKA}

Abdul Kadir Muhammad, 1991, Hukum Pengangkutan Darat, Laut, dan Udara, Penerbit PT. Citra Aditya Bakti, Bandung

-------, 1991, Hukum Pengangkutan
Darat, Laut dan Udara, Citra Aditya Bakti, Bandung.

Ahmad Ichsan, 1981, Hukum DagangPengangkutan, Pradnya Paramita, Jakarta.

Budi F. Supriadi, 2004, Aspek-Aspek Hukum Dalam Perdagangan internasional, Bahan Perkuliahan Hukum Dagang Internasional, FH UNIKOM, Bandung.

------, "Bahan Perkuliahan Hukum Dagang", FH UNIKOM, Bandung,Nopember 2005.

Drion, Limitation of Liability in International Air Law, Martinuss Nijhoff, 1954.

E. Saefullah Wiradipradja, 1989, Tanggung Jawab Pengangkut Dalam Hukum Pengangkutan Udara Internasional dan Nasional, Liberty, Yogyakarta.

------, 1998, Product liability: tanggung jawab produsen di era perdagangan bebas, Jurnal Hukum Bisnis, YPHB.

Edmon Makarim, Kompilasi Hukum Telematika, Raja Grafindo, Jakarta.

Gunawan Wijaya dan Kartini Mulyadi, 2003, Jual Beli: Seri Hukum Perikatan, Rajawali Pers, Jakarta.

Yahya Harahap, 1986, Segi-segi Hukum Perjanjian. Alumni, Bandung. -, 1991, Hukum Perikatan, Citra Aditya Bakti, Bandung. , 1998. Hukum Pengangkutan Niaga, Citra Aditya Bakti, Bandung. 
Hankelsen, Teori Hukum Murni, dasardasar Ilmu Hukum Normatif, diterjemahkan oleh Raisul Muttaqin, cetakan X: Januari 2013

H.M.N. Purwosutjipto, 1999, Pengertian Pokok Hukum Dagang, Jilid I, Djambatan, Jakarta.

------ . 1995, Pengertian Pokok Hukum Dagang Indonesia, Buku 3 Hukum Pengangkutan, Djambatan,Jakarta.

Haris Faulidi Asnawi, 2004, Transaksi Bisnis E-Commerce Perspektif Islam, Magistra Insania Press, Yogyakarta.

Harold Gill Reuschlein, 1990, The Law of Agency And Partnership, Second Edition, West Publishing.

Kenneth W. Clarkson, 1986, West Business Law, Text \& Cases, Third Edition, West Publishing Company, St. Paul.

Komar Kanta, 1994, Tanggung Jawab Profesional, Ghalia Indonesia, Jakarta.

Purwosutjipto, 1991, Pengertian pokok Hukum Dagang Indonesia 3, Hukum Pengangkutan, Djambatan, Jakarta.

--------, 2003, Pengertian Pokok Hukum Dagang, Jilid I, Pengetahuan Dasar Hukum Dagang, Djambatan, Jakarta.

,1991, Pengertian pokok Hukum Dagang Indonesia 3, Hukum Pengangkutan. Jakarta: Djambatan.

R. Subekti, 1989, Aneka Perjanjian, Alumni, Bandung.
1989, Hukum Perjanjian, PT Intermasa, Jakarta.

Riduan Syahrani, 2000, Seluk- Beluk dan Asas-asas Hukum Perdata, Alumni, Bandung.

Ronny Hanijito Soemitro, 1994, Metode Penelitian Hukum dan Jurimetri, Ghalia Indonesi, Jakarta.

Soedjono Dirjosisworo, 2010, Pengantar Ilmu hokum, edisi I cetakan 14, Rajawali Pers , Jakarta.

Soetiksno, 1998, Filsafat Hukum Bagian II, cetakan 6, Pradya Pramita, Jakarta.

Soegiatna Tjakranegara, 1995, Hukum Pengangkutan Barang dan Penumpang, Rineka Cipta, Jakarta.

Soekardono, 1997, Hukum Dagang, Jilid I, Bagian Pertama, Soeroengan, Jakarta.

--------, 2001, Hukum Dagang Indonesia, Jilid II, Rajawali, Jakarta.

Soerjono Soekanto , 1993, Mengenal Sosiologi Hukum, cetakan ke VI, Rajawali Pers, Jakarta.

--------, 2012, Pokok - pokok Sosiologi Hukum, Rajawali Pers, Jakarta.

Subekti, 1991, Hukum Perjanjian, Intermasa, Jakarta.

Sukrisman, 1995, Ekspedisi Muatan (Freight Forwarding), Alumni, Bandung.

Surojo Wignjodipuro, Pengantar dan Asas-asas Hukum Adat, Gunung Agung, Jakarta. 
Suyono, 2001, Shipping Pengankutan Intermodal Ekspor Impor melalui Laut, PPM, Jakarta.

Toto Suriaatmadja, 2005, Pengangkutan Kargo Udara,Pustaka Bani Quraisy, Bandung.

Kitab Undang-Undang Hukum Dagang.

Kitab Undang-Undang Hukum Perdata.

Undang-Undang No. 22 Tahun 2009 tentang Lalu Lintas Dan Angkutan Jalan Raya

PP No. 17 tahun 1988 tentang Penyelenggaraan dan Pengusahaan. Angkutan Laut 